\title{
On Gasohol Production by Extracting Alcohol with Gasoline
}

\author{
Sinjhang Huang ${ }^{1 \mathrm{a}}$ Tzongbin Lin $^{2 \mathrm{~b}}$ Mawtien Lee ${ }^{1 \mathrm{c}^{*}}$
}

1. Department of Applied Chemistry, National Chiayi University, Chiayi City, Taiwan

2. Refining and Manufacturing Research Institute, Chinese Petroleum Corp., Chiayi City, Taiwan

as0952243@mai.ncyu.edu.tw, ${ }^{\mathrm{b}} 077097 @ c p c . c o m . t w,{ }^{\mathrm{c}} \mathrm{mtlee@mai.ncyu.edu.tw}$

Keywords: Gasohol, countercurrent extraction, phase diagram, distribution coefficient

Abstract In this research we explore the feasibility of using commercial gasoline to extract the ethanol from the ethanol solution to produce gasohol. The experiment simulated a 3-stage countercurrent extraction process. Commercial unleaded gasoline with various octane number $(92,95,98)$ was used as solvent to extract the ethanol from ethanol solutions with $80 \% \cdot 90 \%(\mathrm{v} / \mathrm{v})$ of the ethanol content. The experimental results showed gasohol with more than $10 \%(\mathrm{w} / \mathrm{w})$ the ethanol content could be gotten. The phase diagram was also observed at low $\left(0 \sim 1^{\circ} \mathrm{C}\right)$ and room temperature. We found that phase diagrams of water-gasoline-ethanol systems with various octane number of gasoline had no significant difference and the solubility of gasoline in water phase increased with the increase of temperature. It is clearly that gasohol can be produced by extracting the ethanol with commercial gasoline. This process can significantly reduce the energy consumption for the ethanol distillation process. It is a simple and feasible method to produce gasohol.

\section{Introduction}

Gasohol which is refers to the ethanol-gasoline blend has been studied widely (Wu et al 2004, Hsieh et al 2002, Whitten 1998). This fuel can reduce greenhouse gas emissions and enhance the octane number of gasoline. It has the very good effect on the environmental protection. But it has some disputes, because some scholars think that the dehydrated alcohol processes need to consume much energy (Chambers et al 1979).

In order to reduce the energy used in alcohol distillation processes, Leeper and Wanket (1982) proposed the scheme for the separation of the ethanol from water by extraction with gasoline, and presented experimental data on the extraction step. Their experimental results showed that gasohol mixture with $10 \%$ the ethanol can be produced by distillation and then extraction. Lee and Pahl (1985) simulated 3-stage countercurrent extraction scheme and bench-scale continuous extraction. Experimental results showed that E10 (10\%ethanol) gasohol can be produced by extracting ethanol from a $90 \mathrm{wt} \%$ ethanol aqueous solution. The extract technology has the merit which does consume little energy, and the alcohol and the fuel oils can be mutually soluble. Therefore, gasohol production by liquid-liquid extraction is a good choice. In this paper, the ethanol solution with 78wt $\%$ ethanol was successfully extracted with a 3-stage countercurrent extraction scheme for gasohol production.

\section{Experimental Section}

The ethanol, (95 wt\%,) was diluted to $78 \mathrm{wt} \%$ to be the feed. The unleaded gasoline with various octane number $(92,95,98)$, was used as extraction solvent. They were supplied by CPC Corporation (Taiwan). Compositions of the extractive solvents are presented in Table I.

Table I. The Compositions (Vol \%) of the Extraction Solvents

\begin{tabular}{|c|c|c|c|}
\hline & 92 Gasoline & 95 Gasoline & 98 Gasoline \\
\hline n-Paraffins & 11.220 & 9.987 & 7.491 \\
\hline i-Paraffins & 36.316 & 34.326 & 30.589 \\
\hline Olefins & 8.732 & 8.756 & 6.735 \\
\hline Naphtenes & 8.651 & 6.131 & 3.812 \\
\hline
\end{tabular}




\begin{tabular}{|c|c|c|c|}
\hline Aromatics & 24.569 & 28.987 & 38.093 \\
\hline Oxygenates & 9.786 & 11.247 & 11.941 \\
\hline Total unknowns & 0.726 & 0.567 & 1.338 \\
\hline Grand total & 100 & 100 & 100 \\
\hline
\end{tabular}

In order to simulate the countercurrent continuous extraction, a schematic flow diagram of this process is shown in Figure 1. Every stage is assumed to be in equilibrium. The symbols $\mathrm{S}, \mathrm{F}, \mathrm{R}, \mathrm{S}_{\mathrm{n}}$ [n: number] represent fresh solvent, feed to be extracted, raffinate and extract, respectively. The extraction processes were conducted at room temperature and about $0^{\circ} \mathrm{C}$. The time of equilibrium for each step was 5 minutes; solvent to feed ratio was 1.0 (both take approximately $25.000 \mathrm{~g}$ ). After 3-stage extraction, the mass values of the extract and raffinate were recorded and analyzed by GC-FID [Shimadzu GC-14A Gas Chromatograph].

\section{Results and discussion}

The 78wt \% ethanol solution were mutually soluble with all the three extractive solvents (92, 95,98

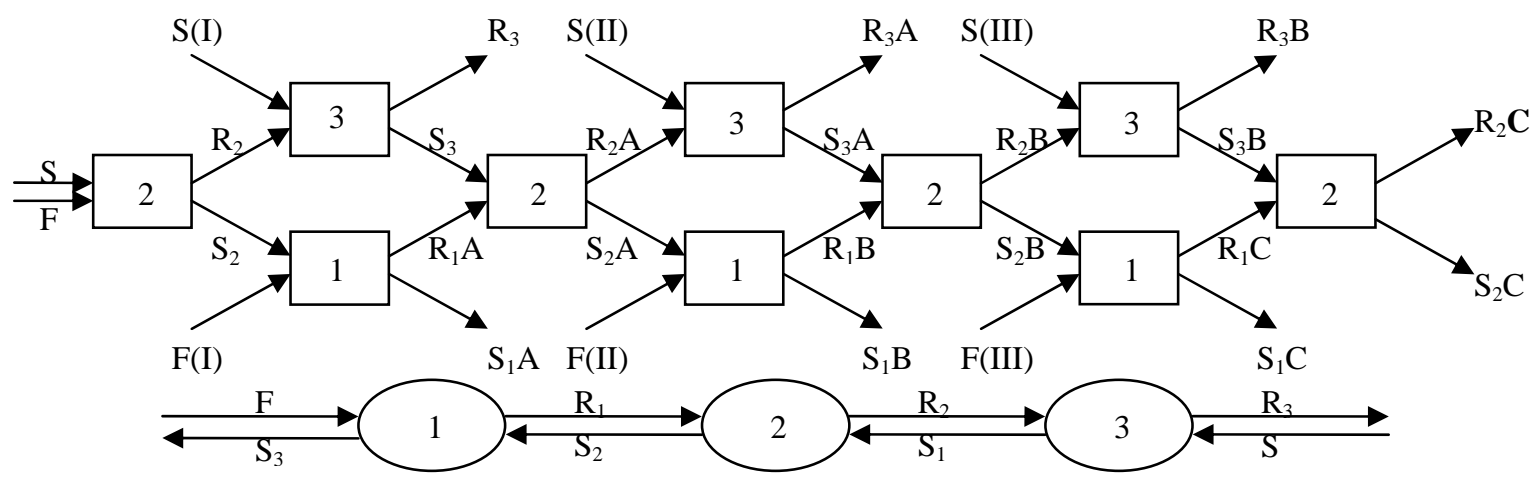

Figure1. Schematic diagram of the 3-stage countercurrent extraction process

(F: feed to be extracted [ethanol], S: fresh solvent, R: raffinate, $S_{n}[n$ : numbers]: extract)

gasoline). The experimental results are presented in Table II. It is clear that more than 10 wt \% ethanol gasohol mixture can be produced by this 3-stage extraction with $78 \mathrm{wt} \%$ ethanol solution as the feed. However the ethanol content in gasohol increased with the increase of octane number of gasoline. In comparison with Table I and Table II, it is clear that the high ethanol content in high octane number gasoline is due to aromatics and oxygenates contents in the extractive solvent, especially aromatics compound.

Table II. Experimental results of a 3-stage countercurrent extraction.

\begin{tabular}{|c|c|c|c|c|c|c|c|}
\hline $\begin{array}{c}\text { composition } \\
\text { input }\end{array}$ & water & ethanol & oil & $\begin{array}{c}\text { composition } \\
\text { outlet }\end{array}$ & water & ethanol & oil \\
\hline 92 Gasoline & $0 \%$ & $0 \%$ & $100 \%$ & extract & $\sim 0 \%$ & $11.31 \%$ & $88.69 \%$ \\
\hline Ethanol solution & $22.18 \%$ & $77.82 \%$ & $0 \%$ & raffinate & $16.97 \%$ & $65.70 \%$ & $17.33 \%$ \\
\hline 95 Gasoline & $0 \%$ & $0 \%$ & $100 \%$ & extract & $\sim 0 \%$ & $14.67 \%$ & $85.33 \%$ \\
\hline Ethanol solution & $22.43 \%$ & $77.57 \%$ & $0 \%$ & raffinate & $17.19 \%$ & $64.50 \%$ & $18.30 \%$ \\
\hline 98 Gasoline & $0 \%$ & $0 \%$ & $100 \%$ & extract & $\sim 0 \%$ & $18.09 \%$ & $81.91 \%$ \\
\hline Ethanol solution & $22.23 \%$ & $77.77 \%$ & $0 \%$ & raffinate & $14.80 \%$ & $64.07 \%$ & $21.13 \%$ \\
\hline
\end{tabular}


Table III. Summary of the distribution coefficient for each stage

\begin{tabular}{|c|c|c|c|}
\hline Solvent & \multirow{2}{*}{92 Gasoline } & 95 Gasoline & \multirow{2}{*}{98 Gasoline } \\
\hline $\mathrm{R}_{2}, \mathrm{~S}_{2}$ & 0.1398 & 0.1431 & 0.1637 \\
\hline $\mathrm{R} 3, \mathrm{~S} 3$ & 0.1491 & 0.1548 & 0.1838 \\
\hline $\mathrm{R}_{1} \mathrm{~A}, \mathrm{~S}_{1} \mathrm{~A}$ & 0.1449 & 0.1514 & 0.1819 \\
\hline $\mathrm{R}_{2} \mathrm{~A}, \mathrm{~S}_{2} \mathrm{~A}$ & $\mathbf{0 . 1 5 4 1}$ & $\mathbf{0 . 1 6 7 7}$ & $\mathbf{0 . 2 1 7 0}$ \\
\hline $\mathrm{R}_{3} \mathrm{~A}, \mathrm{~S}_{3} \mathrm{~A}$ & 0.1698 & 0.1796 & 0.2214 \\
\hline $\mathrm{R}_{1} \mathrm{~B}, \mathrm{~S}_{1} \mathrm{~B}$ & 0.1553 & 0.1788 & 0.2210 \\
\hline $\mathrm{R}_{2} \mathrm{~B}, \mathrm{~S}_{2} \mathrm{~B}$ & $\mathbf{0 . 1 6 8 0}$ & $\mathbf{0 . 1 8 9 1}$ & $\mathbf{0 . 2 4 0 3}$ \\
\hline $\mathrm{R}_{3} \mathrm{~B}, \mathrm{~S}_{3} \mathrm{~B}$ & 0.1677 & 0.2149 & 0.2572 \\
\hline $\mathrm{R}_{1} \mathrm{C}, \mathrm{S}_{1} \mathrm{C}$ & 0.1702 & 0.2062 & 0.2531 \\
\hline $\mathrm{R}_{2} \mathrm{C}, \mathrm{S}_{2} \mathrm{C}$ & $\mathbf{0 . 1 7 2 1}$ & $\mathbf{0 . 2 2 7 5}$ & $\mathbf{0 . 2 8 2 4}$ \\
\hline
\end{tabular}

The distribution coefficients of each step in extraction with $78 \mathrm{wt} \%$ ethanol solution and 92, 95, 98 gasolines were calculated and presented in Table III. .We found that the distribution coefficient for each extraction step also increased with the increase octane number of gasoline. Moreover, we discovered that the $\mathrm{K}$ value increases along with the increase of extract board number. It is believed that the accumulation of aromatics and oxygenates in extracting solvent induces this phenomenon.

The ternary phase diagrams of 92, 95, 98 gasoline-ethanol-water system under the room and low temperature $\left(0 \sim 1{ }^{\circ} \mathrm{C}\right)$ are presented in Figure 2. There is no significant difference for the three types of gasoline. However temperature is an important factor that affects the phase diagrams (Figure 2-a, b). These ternary phase diagrams give the evidence that phase separation may occur for gasohol with water under low temperature.
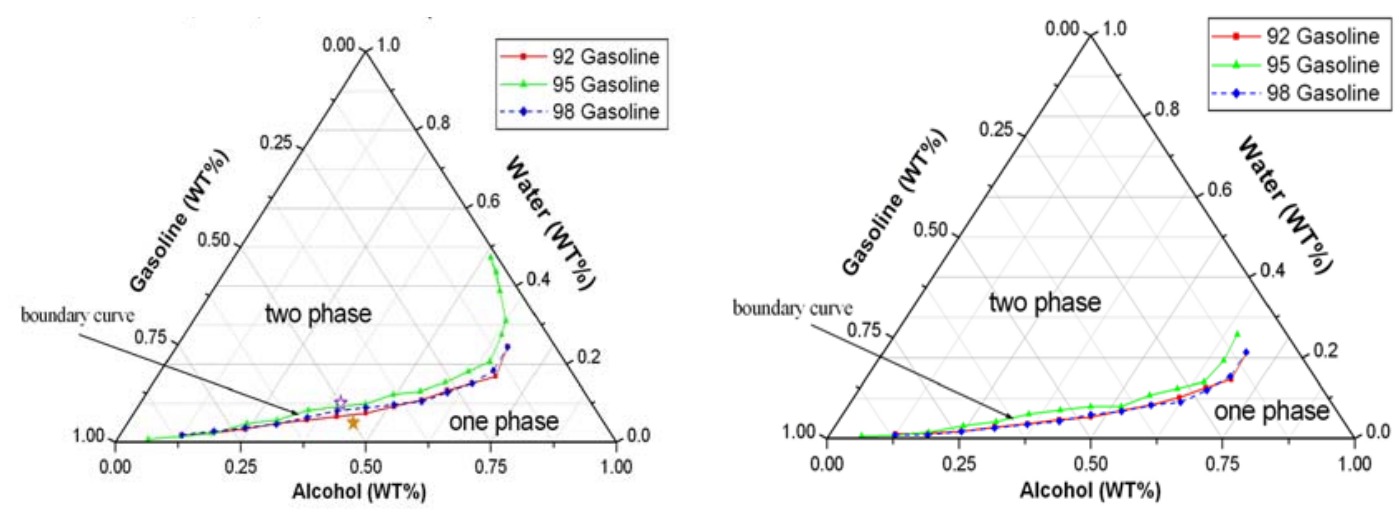

Fig. 2. Ternary phase diagrams of three different gasoline, water and ethanol (a) at room temperature; (b) at low temperature, $0 \sim 1^{\circ} \mathrm{C}$.

\section{Conclusions}

(1) More than $10 \mathrm{wt} \%$ ethanol gasohol can be produced by extracting with the commercial gasoline.

(2) The ethanol concentration in the gasohol is dependent on the amount of aromatics and oxygenates contents of gasoline.

(3) There is no significant difference for the ternary phase diagram of water-gasoline-alcohol for the three commercial gasolines.

(4) Water within the gasohol may induce phase separation under low temperature.

(5) Solvent extraction method can significantly reduce the energy consumption in comparison with the distillation process. It should be a simple and feasible method to produce gasohol. 


\section{References}

[1]. C.W. Wu, R.H. Chen, J.Y. Pu, T.H. Lin, Atmos. Environ. Vol.38 (2004), pp.7093.

[2]. W.D. Hsieh, R.H. Chen, T.L. Wu, T.H. Lin, Atmos. Environ. Vol.36 (2002), pp. 403.

[3]. G.Z. Whitten, Environ. Sci. Technol. Vol.32 (1998), pp. 3840.

[4]. R.S. Chambers, R.A. Heredeen, J.J. Joyce, P.S. Penner., Science Vol.206 (1979), pp.789.

[5]. S.A. Leeper, P.C. Wanket, 1982. , Ind. Eng. Chem. Proc. Des. Dev. Vol.21 (1982), pp. 331

[6]. F.M Lee, R.H. Pahl, 1985. , Ind. Eng. Chem. Proc. Des. Dev. Vol.24 (1985), pp. 250. 